\title{
Role of auxin (IAA) in the regulation of slow vacuolar (SV) channels and the volume of red beet taproot vacuoles
}

\author{
Zbigniew Burdach', Agnieszka Siemieniuk', Zenon Trela, Renata Kurtyka ${ }^{1}$ and Waldemar Karcz ${ }^{*}$
}

\begin{abstract}
Background: Auxin (IAA) is a central player in plant cell growth. In contrast to the well-established function of the plasma membrane in plant cell expansion, little is known about the role of the vacuolar membrane (tonoplast) in this process.

Results: It was found that under symmetrical $100 \mathrm{mM} \mathrm{K}$ and $100 \mu \mathrm{M}$ cytoplasmic $\mathrm{Ca}^{2+}$ the macroscopic currents showed a typical slow activation and a strong outward rectification of the steady-state currents. The addition of IAA at a final concentration of $1 \mu \mathrm{M}$ to the bath medium stimulated the SV currents, whereas at 0.1 and $10 \mu \mathrm{M}$ slight inhibition of SV currents was observed. The time constant, $\tau$, decreased in the presence of this hormone. When single channels were analyzed, an increase in their activity was recorded with IAA compared to the control. The single-channel recordings that were obtained in the presence of IAA showed that auxin increased the amplitude of the single-channel currents. Interestingly, the addition of IAA to the bath medium with the same composition as the one that was used in the patch-clamp experiments showed that auxin decreased the volume of the vacuoles.
\end{abstract}

Conclusions: It is suggested that the SV channels and the volume of red beet taproot vacuoles are modulated by auxin (IAA).

Keywords: Beta vulgaris L., IAA (indole-3-acetic acid), SV channels, Vacuole, Vacuolar volume

\section{Background}

Auxins, particularly indole-3-acetic acid (IAA), play an essential role in the regulation of plant cell extension. According to the so-called "acid growth theory", auxin activates the $\mathrm{PM} \mathrm{H}^{+}$-ATPase, which acidifies the apoplast and causes the activation of the enzymes that are involved in cell wall loosening (for a review see [1]). It is also well established, at least in maize coleoptile cells, that auxin-induced growth involves $\mathrm{K}^{+}$uptake through voltage-dependent, inwardly rectifying $\mathrm{K}^{+}$channels (ZMK1, Zea mays $\mathrm{K}^{+}$channel 1), the activity of which contributes to water uptake and consequently to cell expansion [2, 3]. It has been shown that apart from the posttranslational, auxin-dependent up-regulation of the $\mathrm{K}^{+}$uptake channels, auxin also regulates the expression of the maize $\mathrm{K}^{+}$uptake channel gene ZMK1 [2]. ZMK1

\footnotetext{
*Correspondence: waldemar.karcz@us.edu.pl

'Department of Plant Physiology, Faculty of Biology and Environmental Protection, University of Silesia, Jagiellońska 28, 40-032 Katowice, Poland Full list of author information is available at the end of the article
}

channels are activated by a hyperpolarizing membrane potential and by extracellular apoplastic protons.

Significantly less is known about the role of the vacuolar membrane, the tonoplast, in the auxin-mediated growth of plant cells. Plant cells contain a large central vacuole that occupies up to $95 \%$ of the total cell volume in many mature plant cells. Plant cell expansion is driven by a combination of the osmotic uptake of water into the vacuoles and altered cell wall extensibility. To maintain the turgor pressure of expanding cells, solutes must be transported into the vacuole to maintain its osmolarity. Vacuoles are very dynamic organelles, whose morphology changes during plant growth and development $[4,5]$. It has been shown that auxin (IAA) and its metabolites are present in plant vacuoles and that auxin transport across the tonoplast plays essential roles in maintaining auxin homeostasis [6]. It is also well known that auxin stimulates or inhibits the growth of plant cells depending on its concentration as well as the cell type [7]. Recently, it has been shown that auxin altered the 
appearance of the vacuoles in the root epidermal cells of Arabidopsis thaliana so that they became smaller [8]. At the same time, as these authors showed, auxin also inhibited the growth of the root epidermal cells. This finding was used by Dünser and Kleine-Vehn [9] to propose the "acid growth balloon theory" according to which plant growth is the interplay between the intracellular space-filling "vacuolar balloon" and the required extracellular cell wall acidification/loosening.

Taking into account that plant vacuoles are highly dynamic organelles and are essential for growth and development, we performed experiments in which the effect of auxin (IAA) on the slow vacuolar (SV) channels and the volume of red beet taproot vacuoles were studied. In the plant vacuoles, slow vacuolar (SV) channels are $\mathrm{Ca}^{2+}$-permeable cation channels that are coregulated by voltage and $\mathrm{Ca}^{2+}$. These SV channels are ubiquitous and abundant in the vacuolar membrane of terrestrial plants. The SV channel from Arabidopsis, TPC1, is encoded by the single-copy gene AtTPC1 [10]. Structurally, TPC1 represents a dimer of two Shaker-like monomers that are linked via a cytoplasmic loop that contains two EF hand motifs $([11,12]$ for a review see [13]). The activity of voltage-dependent TPC1 channels can be regulated by both cytosolic and vacuolar $\mathrm{Ca}^{2+}$. Cytosolic $\mathrm{Ca}^{2+}$ promotes channels opening $[12,14]$, whereas luminal $\mathrm{Ca}^{2+}$ prevents their opening [15]. Three decades after the discovery of the SV channels by Hedrich et al. [16] and Hedrich and Neher
[14], two groups of researchers revealed the essential structural and functional properties of TPC1/SV channels in Arabidopsis thaliana based on their crystal structure [17, 18]. Soon after, Jaślan et al. [19] published a paper in which the structural determinants of the voltage- and calcium-dependent channel gating of AtTPC1 were described. For their analysis, these authors built a three-dimensional homology model of AtTPC1 that was based on the crystal structure of the bacterial voltage-gated $\mathrm{Na}^{+}$channel $\mathrm{Na}_{\mathrm{v}} \mathrm{Ab}$. To the best of our knowledge, no research has been reported on the effects of IAA on the TPC1/SV channels in plant cells. We hypothesize that SV channels representing the major cations conductance are involved in auxin-induced volume changes of the vacuoles.

\section{Results}

Effect of IAA on the volume of red beet taproot vacuoles Red beet vacuoles were mechanically isolated directly onto glass slides by rinsing the surface of fresh tissue slices with a medium containing various $\mathrm{K}^{+}$concentrations $(0,20$ and $100 \mathrm{mM})$. As Fig. 1 indicates, the volume of the vacuoles that were incubated in the bath medium without $\mathrm{K}^{+}$and with $1 \mu \mathrm{M}$ IAA increased after $60 \mathrm{~min}$ up to $8 \%$ of their initial value (at $0 \mathrm{~min}$ ). In the presence of IAA, the volume of the vacuoles that had been incubated in bath medium without $\mathrm{K}^{+}$increased by $20 \%$. When the vacuoles were incubated in the presence

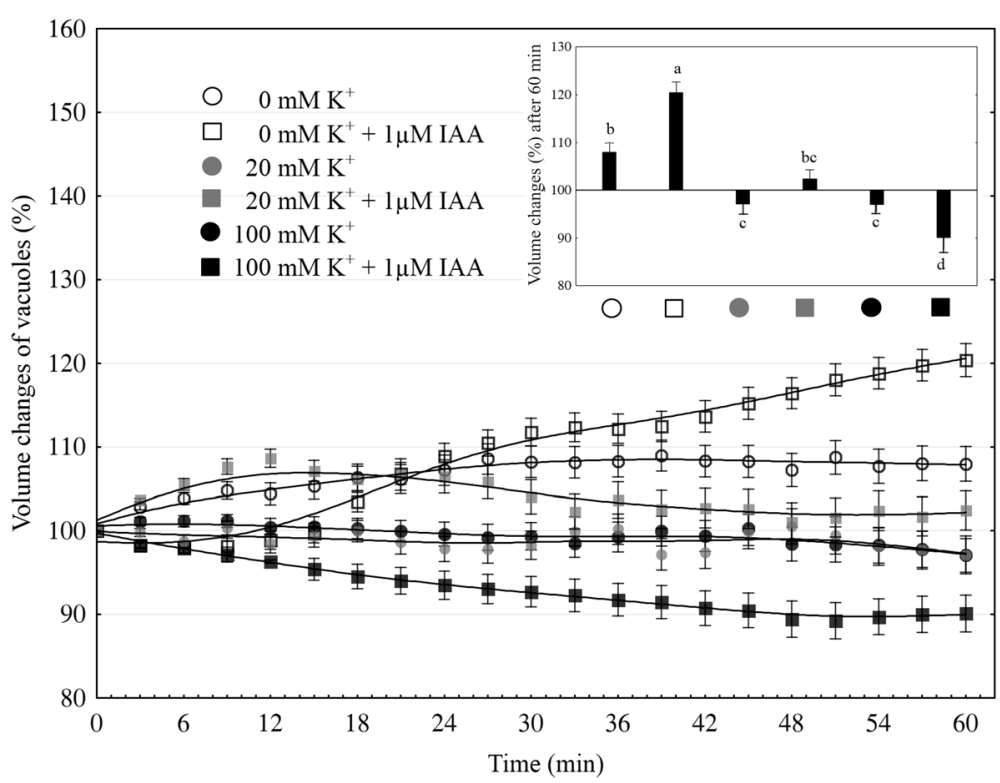

Fig. 1 Effect of $1 \mu \mathrm{M}$ indole-3-acetic acid (IAA) on the volume changes of vacuoles. The vacuoles had been incubated in the presence of $\mathrm{K}^{+}$at 0 , 20 and $100 \mathrm{mM}$. IAA was added to the incubation medium at time $0 \mathrm{~min}$. The data points are the means ( \pm SE) from nine independent experiments. The volume of individual vacuoles was calculated from the diameter of the individual vacuoles in a photographic image. The diameter of the vacuoles was measured at the indicated times and converted to a percentage of the initial value (fixed as 100\%). The inset on the right shows the volume of vacuoles after one hour of the experiment. Bars indicate means \pm SEs. Means followed by the same letter are not significantly different from each other (LSD test $P<0.05$ ) 
of 20 or $100 \mathrm{mM} \mathrm{K}$, their volume was about 3\% lower compared to the first value. The addition of IAA to the bath solution with $20 \mathrm{mM} \mathrm{K}$ slightly increased (by $3 \%$ over $60 \mathrm{~min}$ ) the volume of the vacuoles, while its addition to the medium with $100 \mathrm{mM} \mathrm{K}^{+}$decreased (by $10 \%$ over $60 \mathrm{~min})$ their volume. Interestingly, in the presence of both IAA and $100 \mathrm{mM} \mathrm{K}^{+}$, a decrease in the volume of the vacuoles was observed from the beginning of the experiment. The data obtained in this section clearly showed that the effect of IAA on the volume of red beet vacuoles depends on the potassium concentration.

\section{Electrophysiological experiments}

Using the patch-clamp technique, we examined the effect of IAA on the slow vacuolar (SV) channel activity in red beet (Beta vulgaris L.) taproot vacuoles. Both macroscopic currents (whole-vacuole configuration) and

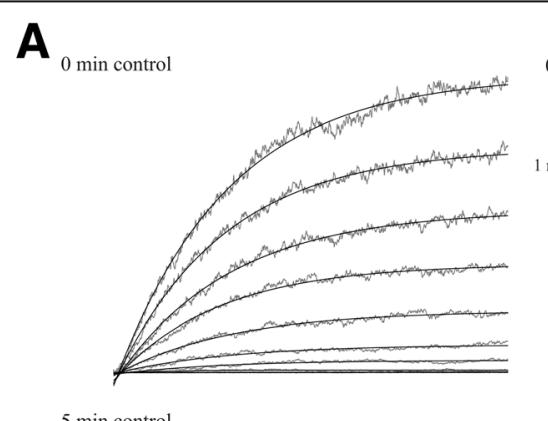

0 min control for $1 \mu \mathrm{M} \mathrm{IAA}$

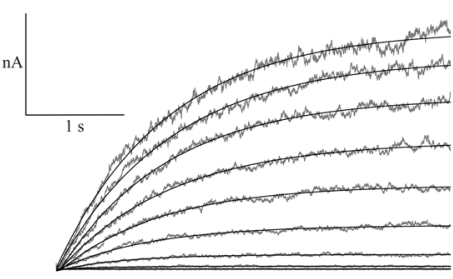

$5 \min 1 \mu \mathrm{M}$ IAA
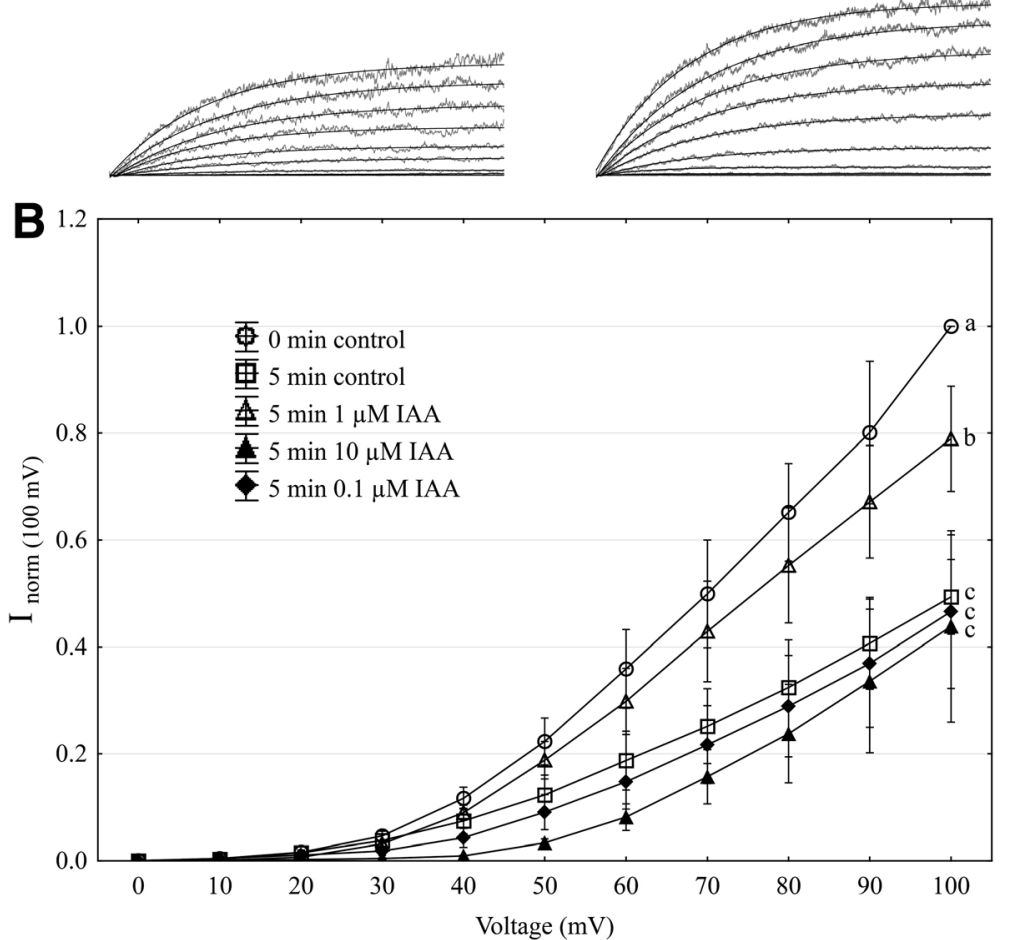

Fig. 2 Effect of cytosolic IAA on the slow vacuolar (SV) channels in red beet taproot vacuoles. a An example of an SV current recording for a single vacuole in the control bath (control at 0 time, recorded immediately after the establishment of the whole-vacuole configuration as well as 5 min later) and in the presence of IAA at $1 \mu \mathrm{M}$ (auxin was added to the bath immediately after the current was recorded in the control at 0 time; however, the current in the presence of IAA was recorded $5 \mathrm{~min}$ after the control at 0 time). SV currents elicited by a series of voltage steps ranging from -100 to $+100 \mathrm{mV}$ in $10 \mathrm{mV}$ steps; holding potential $0 \mathrm{mV}$. b Steady-state currents (normalized to the current amplitude at + $100 \mathrm{mV}$ under control at $0 \mathrm{~min}$ ) were determined in the control medium (control at 0 and $5 \mathrm{~min}$ ) and in the presence of $0.1,1 \mathrm{and} 10 \mu \mathrm{M}$ IAA. The current traces were fitted with the exponential function: $i(t)=a+b(1-\exp (-t / \tau))$, where $a$ - current at $t=0, b$ - current at saturation (plateau), $t$ - time and $\tau$ - time constant. The steady state is the difference between current at saturation (plateau) and current at time " 0 " (leak). Data points are the means $( \pm \mathrm{SE})$ from at least seven experiments performed with different vacuoles. The significance of the results was analyzed for voltage $+100 \mathrm{mV}$ using the post hoc least significant difference (LSD) test. Means followed by the same letter are not significantly different from each other (LSD test $P<0.05)$ 
single-channel currents (cytosolic side-out configuration) were recorded in a symmetrical $100 \mathrm{mM} \mathrm{KCl}$ and $\mathrm{Ca}^{2+}$ gradient $(0.1 \mathrm{mM}$ in the bath and $0 \mathrm{mM}$ in the pipette). It should be added that we decided to use symmetrical $100 \mathrm{mM} \mathrm{KCl}$ for two reasons - firstly, because at symmetrical $100 \mathrm{mM} \mathrm{KCl}$, which is very often used in patch-clamp experiments, the $\mathrm{K}^{+}$current flows from the cytosol to the vacuole and secondly because at this concentration of $\mathrm{KCl}$, auxin, immediately ( $3 \mathrm{~min}$ ) after its addition, causes a decrease in the volume of the vacuoles. The macroscopic current recordings showed slow activation (Fig. 2a, control) and strong outward rectification of the steady-state currents at voltages that were more positive than $+20 \mathrm{mV}$ (Fig. $2 \mathrm{~b}$, control). When IAA at a final concentration of $1 \mu \mathrm{M}$ was added to the bath solution, the SV currents increased at all potentials between +20 and $+100 \mathrm{mV}$ compared to the control at 5 min (Fig. 2b). For example, in the whole-vacuole configuration, the addition of $1 \mu \mathrm{M}$ IAA resulted in a $60 \%$ increase in the current amplitudes at $100 \mathrm{mV}$ compared to the control at $5 \mathrm{~min}\left(\mathrm{I}_{\text {norm }}=0.49 \pm 0.07 \mathrm{SE}\right.$ for control $5 \mathrm{~min}$ and $\mathrm{I}_{\text {norm }}=0.79 \pm 0.1 \mathrm{SE}$ for $1 \mu \mathrm{M}$ IAA $5 \mathrm{~min}$ ). Interestingly, at concentrations 0.1 and $10 \mu \mathrm{M}$ IAA cause only slight changes of steady-state current as compared to the control at $5 \mathrm{~min}$. Therefore for further electrophysiological experiments $1 \mu \mathrm{M}$ concentration of IAA was chosen. As is presented in Fig. 2, the activity of ion channels can be lost during patch-clamp experiments, which is known as "run down". The "run down" defined as inhibition of SV channel activity in time, particularly visible in the whole-vacuole configuration, is a common phenomenon described in numerous publications [2027]. However the opposite effect i.e. the increase of SV channel activity in time was also observed [28]. Fig. 3 presents the time constants, $\tau$, of the monoexponential function fitted to the time courses of the macroscopic SV currents that were recorded in the presence and absence of IAA. These constants can be interpreted as the rate of the SV channel activation after the application of a voltage pulse. Fig. 3 indicates that at voltages between +60 and + $90 \mathrm{mV}$, the time constants, $\tau$, decrease in the presence of IAA by ca. $30 \%$ (for example at $+80 \mathrm{mV}, \tau=1.146 \pm 0.067$ $\mathrm{SE}$ for control $5 \mathrm{~min}$ and $\tau=0.884 \pm 0.09$ SE for IAA $5 \mathrm{~min}$, at $+70 \mathrm{mV}, \mathrm{\tau}=1.298 \pm 0.077 \mathrm{SE}$ for control $5 \mathrm{~min}$ and $\tau=0.851 \pm 0.066 \mathrm{SE}$ for IAA $5 \mathrm{~min}$,), thus suggesting faster channel activation with IAA. At 40, 50 and $100 \mathrm{mV}$ the time constant did not depend on IAA. When considering the microscopic currents in the cytosolic side-out configuration (Fig. 4), channels that had a higher current amplitude could be recorded in the presence of IAA compared to the control at $5 \mathrm{~min}$. This is evident in Fig. 5, which shows that at voltages between 80 and $100 \mathrm{mV}$ auxin significantly increased the amplitude of the SV currents compared to the control at $5 \mathrm{~min}$ (for example at + $100 \mathrm{mV} I=1.957 \pm 0.388 \mathrm{SE}$ for control $5 \mathrm{~min}$ and $I=$ $2.762 \pm 0.124$ SE for IAA $5 \mathrm{~min}$ ). Taking into account the density of the SV channels calculated as whole-vacuole current divided by current of the single channel and surface area of the vacuole, IAA increased number of active SV channels as compared to the control after $5 \mathrm{~min}$. For example, the density of the channels in control at $0 \mathrm{~min}$ amounted 795 channels per $1000 \mu^{2}$ while 5 min later

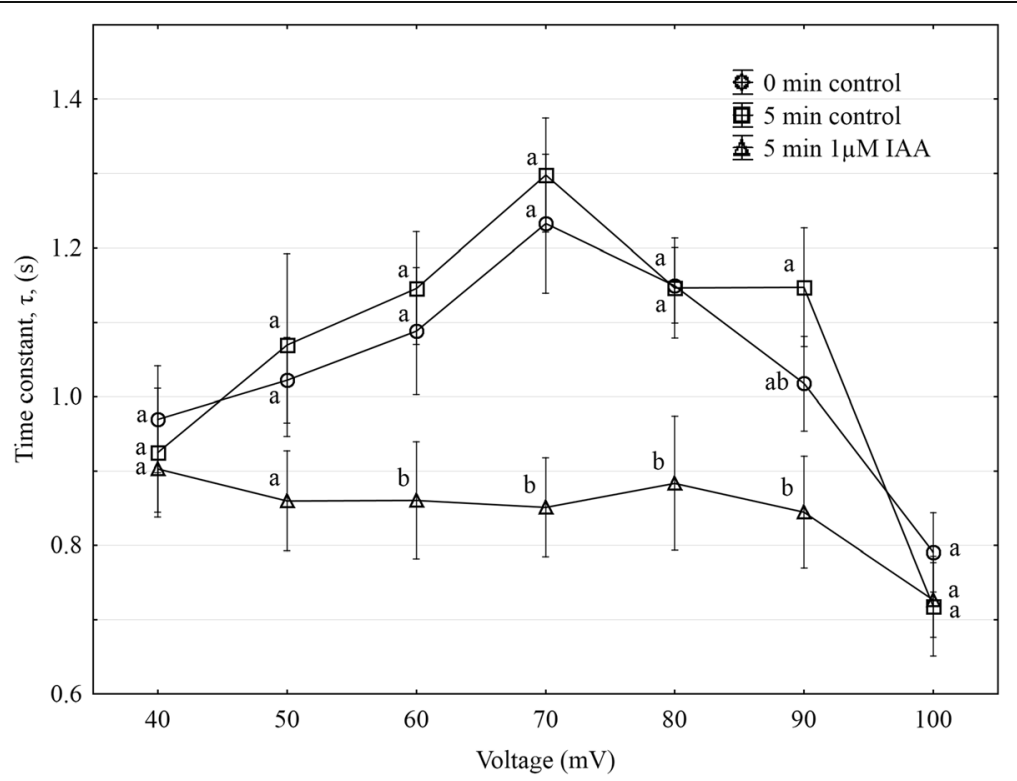

Fig. 3 Effect of IAA at $1 \mu \mathrm{M}$ on activation time, $\tau$, as a function of voltage. Data points are the means ( \pm SE) from at least seven experiments performed with different vacuoles. The significance of the results was analyzed for every voltage $(+40 \mathrm{mV}$ to $+100 \mathrm{mV})$ using the post hoc least significant difference (LSD) test. Means followed by the same letter are not significantly different from each other (LSD test $P<0.05$ ) 


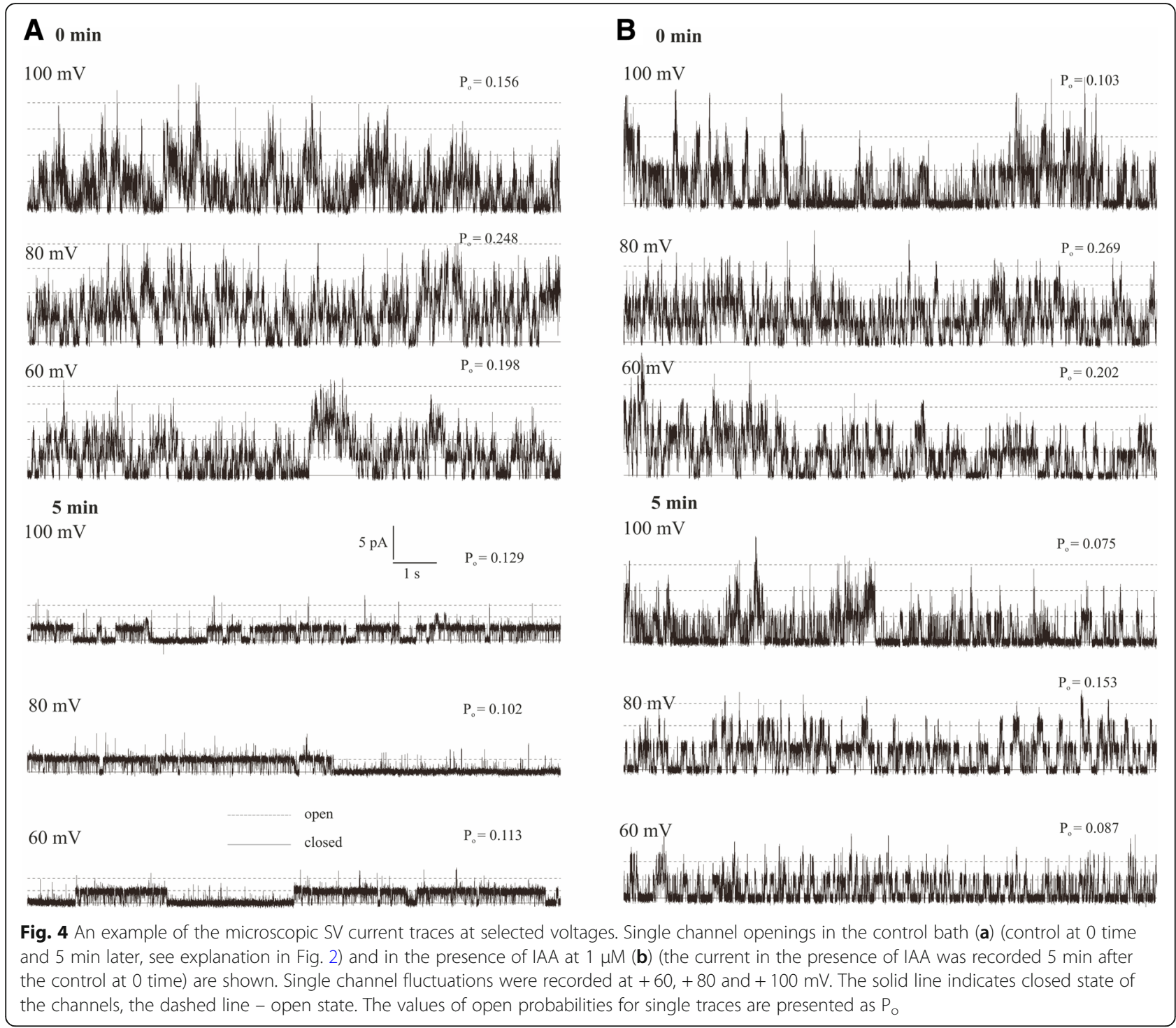

this parameter was 600 channels per $1000 \mu \mathrm{m}^{2}$. In the presence of IAA 5 min after its addition the density of the channels was equal 724 per $1000 \mu^{2}$ (the density values were calculated for $+100 \mathrm{mV}$ ). All of the points in the scatter plots (Fig. 6), which show the distribution of the times of the different current state events as a function of the amplitude of the current, indicate the events of the closing or opening of one, two, three and four SV channels. As can be seen at Fig. 6a the current amplitude of single channels in the presence of IAA is maintained at the level comparable with that recorded for the control at 0 min. Fig. $6 \mathrm{~b}$ and c, which show the average values of the times and the number of events (closed, open) versus the current level, respectively do not show the significant difference between control and IAA after $5 \mathrm{~min}$. As can be seen in Fig. 7, the open probability of single channels at $80 \mathrm{mV}$ was threefold higher in the presence of IAA compared to the control at $5 \mathrm{~min}$, while at the remaining voltages, it was similar to the control values.

Taken together, our electrophysiological data suggest that in a whole-vacuolar configuration, (1) auxin at $1 \mu \mathrm{M}$ enhanced the SV channel activity compared to the control, (2) the time constant, $\mathrm{\tau}$, in the range $40-90 \mathrm{mV}$ decreased in the presence of IAA at $1 \mu \mathrm{M}$, (3) auxin at $1 \mu \mathrm{M}$ increased the amplitude of the SV currents compared to the control and (4) the open probability of single channels was only significantly higher at $80 \mathrm{mV}$ compared to the control.

\section{Discussion}

The tonoplast regulates the traffic of ions and metabolites between the cytosol and the vacuole, which are necessary for plant cell growth. In recent few years the interest in vacuoles increased also in the aspect of auxin 


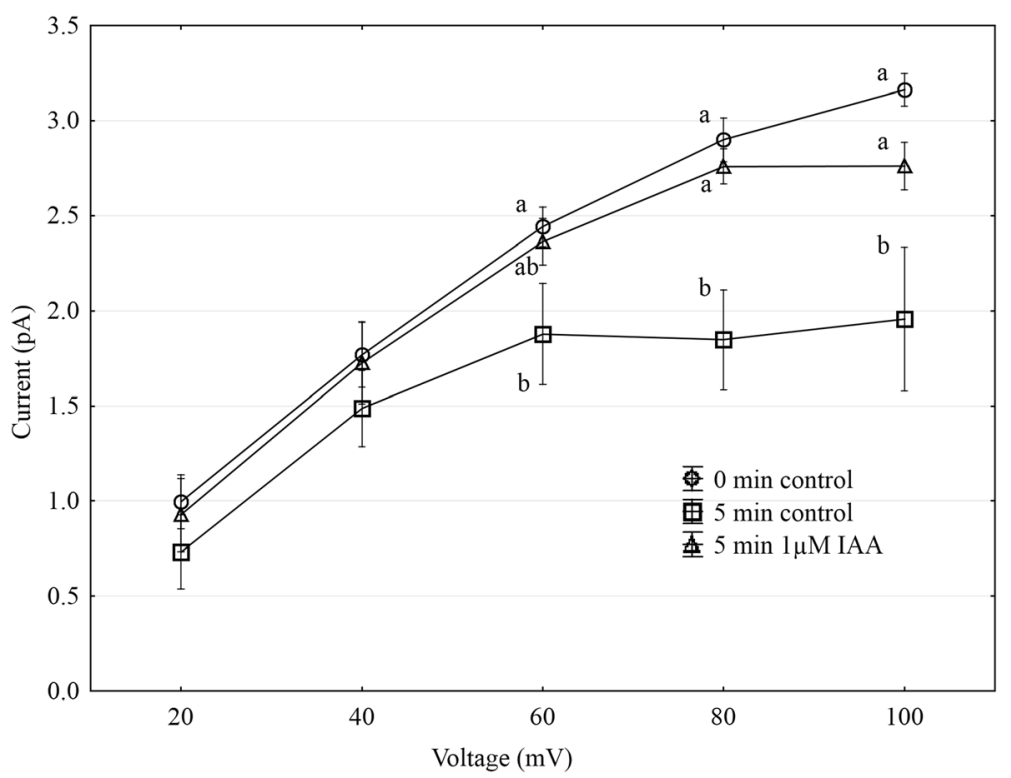

Fig. 5 Current-voltage relationships for the microscopic SV currents. The currents were recorded in the control bath (control at 0 time and 5 min later) and in the presence of IAA at $1 \mu \mathrm{M}$. Points represent the means ( $\pm \mathrm{SE}, n=8$ ) for the events of "open 1" that were recorded at selected voltages. The significance of the results was analyzed for every voltage (+60 mV to $+100 \mathrm{mV}$ ) using the post hoc least significant difference (LSD) test. Means followed by the same letter are not significantly different from each other (LSD test $P<0.05$ )

action in plant cell growth and development. The identification of tonoplast permease WAT1 transporting auxin out of the vacuole and the inverse correlation between auxin content in plant cell and its vacuolation status give new insight on role of vacuoles in auxin homeostasis $[6$, 29]. As hitherto interest focused on the role of vacuoles in auxin redistribution in the cell, our goal was to determine the auxin impact on vacuole volume changes and probable contribution of tonoplast cation channels (TPC1/SV) in this process.

In our experiments, the vacuoles that had been incubated in a medium without $\mathrm{K}^{+}$and $1 \mu \mathrm{M}$ IAA were found to swell (about $8 \%$ ) over first $60 \mathrm{~min}$, while a significantly faster increase in the volume of the vacuoles (ca. twofold) was observed in the presence of $1 \mu \mathrm{M}$ IAA (Fig. 1). The fact that the increase or decrease of the volume of the vacuoles is sensitive to IAA and depends on the $\mathrm{K}^{+}$concentration suggests that the electrical potential of the tonoplast may play a role in this phenomenon. It was previously shown that at high external potassium concentrations, which are comparable to cytosolic values, the membrane potential of the vacuoles that had been isolated from the storage roots of red beet was almost completely abolished, whereas at $0 \mathrm{mM} \mathrm{K}^{+}$, it was around $+75 \mathrm{mV}$ $[30,31]$. The electrical potential and the $\mathrm{pH}$ gradient across the tonoplast provide the driving forces for the transport and accumulation of metabolites and ions in the vacuolar lumen. However, to date, it is not clear how auxin changes the ion transport across the vacuolar membrane of plant cells. Taking the above into account, we performed experiments in which the effect of auxin (IAA) on the SV channel activity in the vacuolar membrane of red beet vacuoles was studied. It is well established that these channels and $\mathrm{H}^{+}$pumps represent the major conductance of the vacuolar membrane (reviewed in $[13,32]$ ). Here, we demonstrate that under the experimental conditions of this study (symmetrical $100 \mathrm{mM} \mathrm{KCl}$ and $\mathrm{Ca}^{2+}$ gradient), vacuoles that had been isolated from the red beet taproot were characterized by SV channels whose electrical properties, such as slow activation and outward rectification, are close to those that were previously described in Beta vulgaris taproots [14, 33, 34]. The addition of $1 \mu \mathrm{M}$ IAA to the bath solution enhanced the SV currents compared to the control (Fig. 2). It is suggested that the stimulation of the macroscopic SV currents that were observed in the presence of IAA may indicate that auxin either acts directly as a channel activator or that it indirectly alters the kinetics of the transition between the closed and open state of a channel. Analysis of the kinetics of the relaxation of macroscopic current may be a source of information on channel gating. Comparing the data that was obtained from the whole-vacuole and single channel recordings, it might be suggested that IAA at $1 \mu \mathrm{M}$ enhanced the SV currents as a result of the faster channel activation, the increased amplitude of SV currents and a higher open probability of single channels at $80 \mathrm{mV}$.

In order to explain the mechanism of the modulation of the SV channel by auxin, two scenarios are possible: (1) at the $\mathrm{pH}$ of the incubation medium used in the experiments $(\mathrm{pH} 7.5)$, the anionic form of IAA $\left(\mathrm{IAA}^{-}\right)$ 


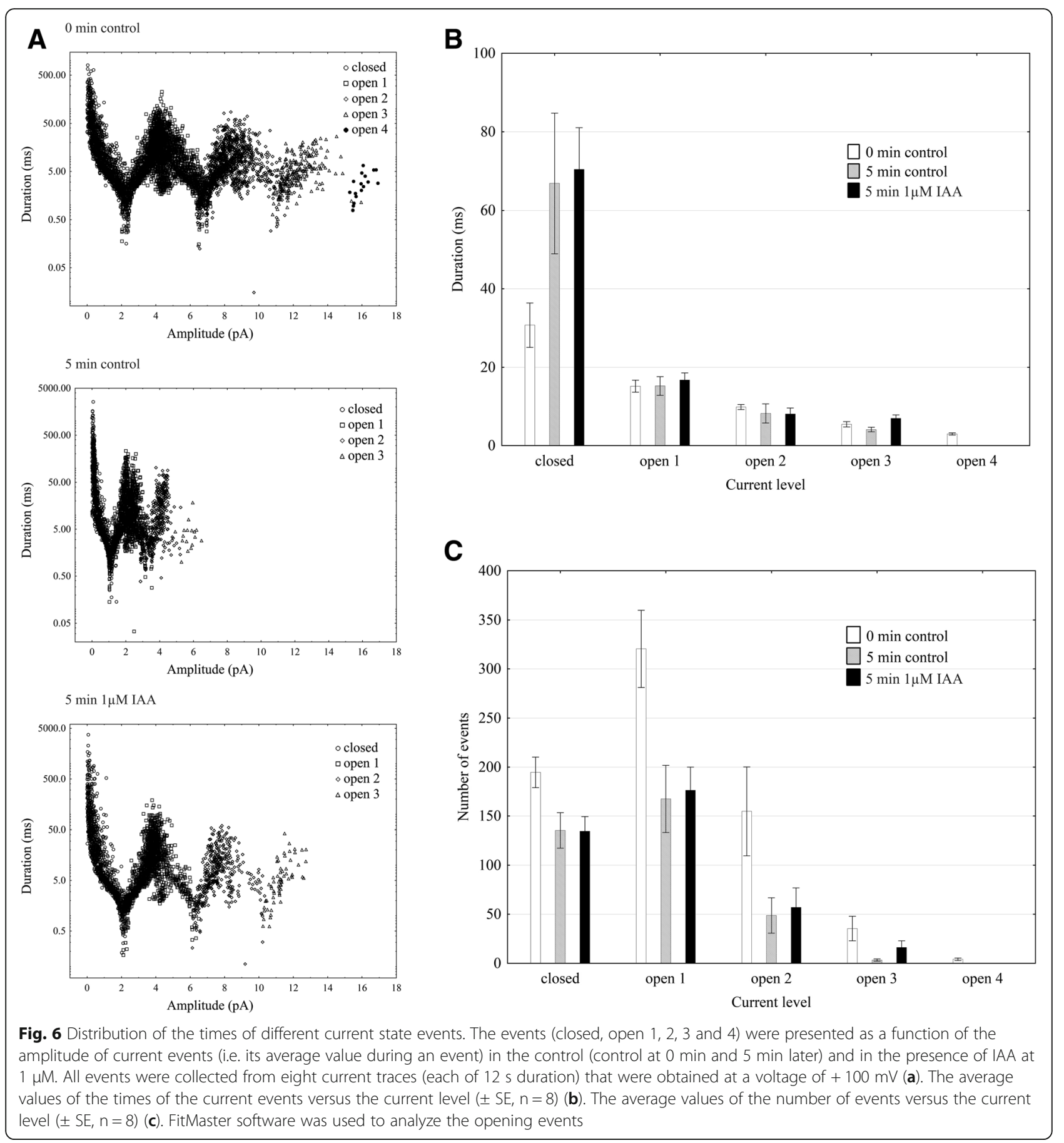

predominates, which can interact with the voltage sensing S10 domain, thus causing changes in the gating kinetics of the SV channel (for the structure of the TPC1 channel, see [17-19] and (2) because auxins are able to interact with lipids and change the properties of the lipid bilayer [35-37], they may disturb the interaction between lipids and proteins and therefore indirectly modulate the activity of the SV channels.
When comparing our electrophysiological experiments with ones in which the diameters of vacuoles were measured, it should be concluded that IAA at $1 \mu \mathrm{M}$ increased the SV channel currents while it decreased the volume of the vacuoles. Taking the above into account, it might be hypothesized that in the presence of IAA, the SV channels play a role in the intracellular space-filling function of the vacuole ("vacuolar balloon"). In agreement with our 


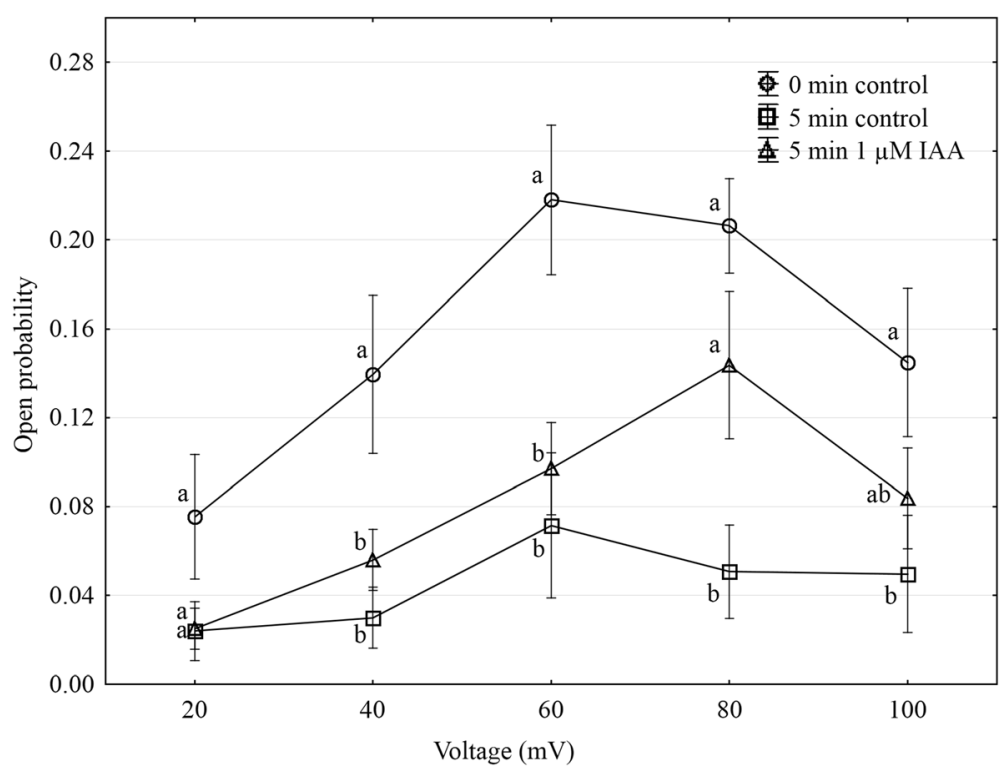

Fig. 7 Open probability of the slow vacuolar (SV) channels as a function of voltage. The open probability was calculated (using FitMaster software) as the sum of the channel open time in the current traces that were normalized to the total time of the traces and divided by the number of active channels in the patch. Data points are the means ( \pm SE) from eight independent experiments. The significance of the results was analyzed for every voltage using the post hoc least significant difference (LSD) test. The significance of the results was analyzed for every voltage (+ $20 \mathrm{mV}$ to $+100 \mathrm{mV}$ ) using the post hoc least significant difference (LSD) test. Means followed by the same letter are not significantly different from each other (LSD test $P<0.05)$

hypothesis, the IAA-induced uptake of $\mathrm{K}^{+}$[2] and probably $\mathrm{Cl}^{-}$([38] and references therein) into the cytoplasm of plant cells might be partly (apart from maintenance of turgor pressure of expanding cell) compensated for by a decrease in the vacuole volume in order to maintain cytoplasm homeostasis. Nevertheless the results presented in this paper indicate that there is no simple interrelation between SV channels activity and volume changes of the vacuoles in the presence of IAA.

\section{Conclusions}

Taken together, our results suggest that auxin enhances the SV currents in red beet vacuoles as a result of a faster channel activation, an increased amplitude of SV currents and a higher open probability of single channels at $80 \mathrm{mV}$, thus simultaneously causing a decrease in vacuole volume. It is suggested that auxin (IAA)), at least at $1 \mu \mathrm{M}$, modulate the SV channels and the volume of red beet taproot vacuoles.

\section{Methods}

\section{Plant material and vacuole isolation}

Red beet (Beta vulgaris L.) taproots vacuoles were isolated using the nonenzymatic method that was previously described by Coyaud et al. [39]. In the experiments in which the diameter of the vacuoles or SV channel activity were measured, the vacuoles were mechanically isolated directly onto glass slides or into an electrophysiological chamber ( $1 \mathrm{ml}$ in volume) by rinsing the surface of fresh tissue slices with the bath solution.

\section{Vacuole volume measurements}

Vacuole diameters were measured using an Ax70 microscope (Olympus Provis) with a fully automatic photomicrography that was connected to a camera (Hammamatsu, Japan). The volume of the vacuoles was measured in a bath solution containing: (1) $100 \mathrm{mM} \mathrm{K}^{+}$ (100 mM KCl, $2 \mathrm{mM} \mathrm{MgCl}$, $0.1 \mathrm{mM} \mathrm{CaCl}, 2 \mathrm{mM} \mathrm{DTT}$, $5 \mathrm{mM}$ MES, $5 \mathrm{mM}$ Tris and $400 \mathrm{mM}$ sorbitol, $\mathrm{pH} 7.5$, osmolality $650 \mathrm{mOsm}),(2) 20 \mathrm{mM} \mathrm{K}{ }^{+}(20 \mathrm{mM} \mathrm{KCl}$, $2 \mathrm{mM} \mathrm{MgCl}_{2}, 0.1 \mathrm{mM} \mathrm{CaCl}, 2 \mathrm{mM}$ DTT, $5 \mathrm{mM}$ MES, $5 \mathrm{mM}$ Tris and $460 \mathrm{mM}$ sorbitol, $\mathrm{pH} 7.5$, osmolality $650 \mathrm{mOsm})$ and (3) $0 \mathrm{mM} \mathrm{K}^{+}(0 \mathrm{mM} \mathrm{KCl}, 2 \mathrm{mM} \mathrm{MgCl} 2$, $0.1 \mathrm{mM} \mathrm{CaCl}_{2}, 2 \mathrm{mM}$ DTT, $5 \mathrm{mM}$ MES, $5 \mathrm{mM}$ Tris and $600 \mathrm{mM}$ sorbitol, pH 7.5, osmolality $650 \mathrm{mOsm})$.

\section{Patch-clamp measurements}

The electrophysiological experiments were performed in whole-vacuole and excised cytosolic side-out patch configuration. The recordings were made using an EPC-7 Plus amplifier (List-Medical-Electronic, Darmstadt, Germany), as was recently described by Trela et al. [40]. For signal filtration a five-pole Bessel filter was used with sampling frequency of 1 to $100 \mathrm{kHz}$. The patch pipettes 
were prepared from borosilicate glass tubes (Kimax-51, Kimble Products, Toledo, Ohio, USA) in accordance with the procedure previously described by us [40]. Voltage pulse within a range of 300 to $900 \mathrm{mV}$ combined with gentle suction let gain the access to the vacuole interior. The current and voltage signs were in accordance with the convention proposed by Bertl et al. [41].

The control bath solution in the patch-clamp experiments was the same as the one that was used for the vacuole diameter measurements (solution number 1). The pipettes were filled with a solution containing $100 \mathrm{mM} \mathrm{KCl}, 2 \mathrm{mM}$ $\mathrm{MgCl}_{2}, 5 \mathrm{mM}$ MES, $5 \mathrm{mM}$ Tris and $\mathrm{pH}$ 5.5, which was adjusted to an osmolality of $580 \mathrm{mOsm}$ with sorbitol. The osmolality of all of the media used during the measurements was adjusted by a cryoscopic osmometer (Semi-Micro Osmometer K-7400, Knauer, Germany). It is well established that under symmetrical $100 \mathrm{mM} \mathrm{K}^{+}$and micromolar cytosolic $\mathrm{Ca}^{2+}$ concentrations, the $\mathrm{SV}$ channels $\mathrm{K}^{+}$ current is outwardly directed. Nevertheless at a calcium gradient $(0.1 \mathrm{mM}$ in the bath and $0 \mathrm{mM}$ in the pipette), a Ca ${ }^{+}$current into the vacuole cannot be excluded at depolarizing voltages. Due to the lack of specific inhibitors of these channels (for a review see [13]) separation of the $\mathrm{K}^{+}$and $\mathrm{Ca}^{2+}$ currents through the SV channels is difficult. The effect of indole-3-acetic acid (IAA) on the SV channels and the volume of the vacuoles were studied. Concentration of IAA $(1 \mu \mathrm{M})$ was selected from among three tested concentrations $(0.1,1$ and $10 \mu \mathrm{M})$ as the one that caused the most significant increase in vacuole volume and change in SV activity in whole-vacuole configuration. In the experiments, the control bath was changed for a new one with the same salt composition that additionally contained IAA at a final concentration of $1 \mu \mathrm{M}$. The exchange of the bath solution in the recording chamber was accomplished through the continuous perfusion of the measuring chamber using an SP200 infusion pump (World Precision Instruments, USA). All of the experiments were carried out at room temperature $\left(22 \pm 1{ }^{\circ} \mathrm{C}\right)$.

Data were stored and elaborated using PatchMaster, FitMaster (HEKA Electronic, Lambrecht, Germany) and Dell Statistica (data analysis software system), version 13. Analysis of the results was performed in accordance with our earlier paper [40]. The opening probability was calculated as the total opening time normalized to the total recording time and the number of active channels in a patch [42].

\section{Abbreviations}

AtTPC1: Arabidopsis thaliana two-pore channel 1; IAA: Indole-3-acetic acid; $\mathrm{Na}_{v} \mathrm{Ab}$ : voltage-gated sodium from Arcobacter butzleri; PM: Plasma membrane; SV: Slow vacuolar channels; TPC1: Two-pore channel 1; WAT1: Walls are thin1; ZMK1: Zea mays $\mathrm{K}^{+}$channel 1

\section{Availability of data and materials}

All data generated or analyzed during this study are included in this published article.
Authors' contributions

Design of work: WK. Performed experiments: ZB, AS. Data analysis: ZB, AS, ZT, RK. Write paper: WK, ZB. All authors read and approved the final manuscript.

Ethics approval and consent to participate

No permission is needed for the collection of plant materials used in this study.

Competing interests

The authors declare no competing interests.

\section{Author details}

'Department of Plant Physiology, Faculty of Biology and Environmental Protection, University of Silesia, Jagiellońska 28, 40-032 Katowice, Poland. ${ }^{2}$ Department of Physics and Biophysics, Wrocław University of Environmental and Life Sciences, Norwida 25, 50-375 Wrocław, Poland.

Received: 20 October 2017 Accepted: 24 May 2018

Published online: 04 June 2018

\section{References}

1. Hager A. Role of the plasma membrane $\mathrm{H}^{+}$-ATPase in auxin-induced elongation growth: historical and new aspects. J Plant Res. 2003;116: 483-505.

2. Philippar K, Fuchs I, Lüthen H, Hoth S, Bauer CS, Haga K, et al. Auxininduced $\mathrm{K}^{+}$channel expression represents an essential step in coleoptile growth and gravitropism. Proc Natl Acad Sci U S A. 1999;96:12186-91.

3. Becker $D$, Hedrich R. Channelling auxin action: modulation of ion transport by indole-3-acetic acid. Plant Mol Biol. 2002;49:349-56.

4. Martinoia E, Meyer S, De Angeli A, Nagy R. Vacuolar transporters in their physiological context. Annu Rev Plant Biol. 2012;63:183-213.

5. Zhang C, Hicks GR, Raikhel NV. Plant vacuole morphology and vacuolar trafficking. Front Plant Sci. 2014:5:476.

6. Ranocha P, Dima O, Nagy R, Felten J, Corratgé-Faillie C, Novák O, et al. Arabidopsis WAT1 is a vacuolar auxin transport facilitator required for auxin homoeostasis. Nat Commun. 2013;4:2625.

7. Sauer M, Robert S, Kleine-Vehn J. Auxin: simply complicated. J Exp Bot. 2013; 64:2565-77.

8. Löfke C, Dünser K, Scheuring D, Kleine-Vehn J. Auxin regulates SNAREdependent vacuolar morphology restricting cell size. eLife. 2015;4:e05868.

9. Dünser K, Kleine-Vehn J. Differential growth regulation in plants - the acid growth balloon theory. Curr Opin Plant Biol. 2015;28:55-9.

10. Peiter E, Maathuis FJ, Mills LN, Knight H, Pelloux J, Hetherington AM, et al. The vacuolar $\mathrm{Ca}^{2+}$-activated channel TPC1 regulates germination and stomatal movement. Nature. 2005:434:404-8.

11. Ishibashi K, Suzuki M, Imai M. Molecular cloning of a novel form (tworepeat) protein related to voltage-gated sodium and calcium channels. Biochem Biophys Res Commun. 2000:270:370-6.

12. Schulze $C$, Sticht $H$, Meyerhoff $P$, Dietrich P. Differential contribution of EFhands to the $\mathrm{Ca}^{2+}$-dependent activation in the plant two-pore channel TPC1. Plant J. 2011;68:424-32.

13. Hedrich R, Marten I. TPC1-SV channels gain shape. Mol Plant. 2011:4:428-41.

14. Hedrich $\mathrm{R}$, Neher E. Cytoplasmic calcium regulates voltage-dependent ion channels in plant vacuoles. Nature. 1987;329:833-6.

15. Dadacz-Narloch B, Beyhl D, Larisch C, López-Sanjurjo EJ, Reski R, Kuchitsu K, et al. A novel calcium binding site in the slow vacuolar cation channel TPC1 senses luminal calcium levels. Plant Cell. 2011;23:2696-707.

16. Hedrich R, Flügge UI, Fernandez JM. Patch-clamp studies of ion transport in isolated plant vacuoles. FEBS Lett. 1986;204:228-32.

17. Guo J, Zeng W, Chen Q, Lee C, Chen L, Yang Y, et al. Structure of the voltage-gated two-pore channel TPC1 from Arabidopsis thaliana. Nature. 2016;531:196-201.

18. Kintzer AF, Stroud RM. Structure, inhibition, and regulatory sites of TPC1 from Arabidopsis thaliana. Nature. 2016:531(7593):258.

19. Jaślan D, Mueller TD, Becker D, Schultz J, Cuin TA, Marten I, et al. Gating of the two-pore cation channel AtTPC1 in the plant vacuole is based on a single voltage-sensing domain. Plant Biol. 2016;18:750-60.

20. Carpaneto A, Cantù AM, Gambale F. Redox agents regulate ion channe activity in vacuoles from higher plant cells. FEBS Lett. 1999;442:129-32.

21. Dobrovinskaya OR, Muniz J, Pottosin II. Inhibition of vacuolar ion channels by polyamines. J Membr Biol. 1999;167:127-40. 
22. Dziubińska H, Filek M, Szechyńska-Hebda M, Trębacz K. Slow vacuolar channels of non-embryogenic and embryogenic cultures of winter wheat. Acta Physiol Plant. 2003;25:179-84.

23. Dziubinska H, Filek M, Krol E, Trebacz K. Slow vacuolar channels in vacuoles from winter and spring varieties of rape (Brassica napus). J Plant Physiol. 2008;165:1511-8.

24. Dziubinska H, Filek M, Krol E, Trebacz K. Cadmium and selenium modulate slow vacuolar channels in rape (Brassica napus) vacuoles. J Plant Physiol. 2010;167:1566-70.

25. Pottosin II, Dobrovinskaya OR, Muniz J. Conduction of monovalent and divalent cations in the slow vacuolar channel. J Membr Biol. 2001;181:55-65.

26. Pottosin II, Wherrett T, Shabala S. SV channels dominate the vacuolar $\mathrm{Ca}^{2+}$ release during intracellular signaling. FEBS Lett. 2009;583:921-6.

27. Wang $Y$, Dindas J, Rienmüller F, Krebs M, Waadt R, Schumacher $K$, et al. Cytosolic $\mathrm{Ca}^{2+}$ signals enhance the vacuolar ion conductivity of bulging Arabidopsis root hair cells. Mol Plant. 2015;8:1665-74.

28. Maathuis FJ, Prins HB. Inhibition of inward rectifying tonoplast channels by a vacuolar factor: physiological and kinetic implications. J Membr Biol. 1991; 122:251-8.

29. Kramer EM, Ackelsberg EM. Do vacuoles obscure the evidence for auxin homeostasis? Mol Plant. 2016;9:4-6.

30. Doll S, Hauer R. Determination of the membrane potential of vacuoles isolated from red-beet storage tissue. Planta. 1981;152:153-8.

31. Miller AJ, Brimelow JJ, John P. Membrane-potential changes in vacuoles isolated from storage roots of red beet (Beta vulgaris L.). Planta. 1984; 160:59-65.

32. Hedrich R. Ion channels in plants. Physiol Rev. 2012;92:1777-811.

33. Schulz-Lessdorf B, Hedrich R. Protons and calcium modulate SV-type channels in the vacuolar-lysosomal compartment - channel interaction with calmodulin inhibitors. Planta. 1995;197:655-71.

34. Gambale F, Bregante M, Stragapede F, Cantu AM. Ionic channels of the sugar beet tonoplast are regulated by a multi-ion single-file permeation mechanism. J Membr Biol. 1996;154:69-79.

35. de Melo MP, de Lima TM, Pithon-Curi TC, Curi R. The mechanism of indole acetic acid cytotoxicity. Toxicol Lett. 2004;148:103-11.

36. Celik I, Tuluce Y, Isik I. Influence of subacute treatment of some plant growth regulators on serum marker enzymes and erythrocyte and tissue antioxidant defense and lipid peroxidation in rats. J Biochem Mol Toxicol. 2006;20:174-82.

37. Hąc-Wydro K, Sroka A, Jabłońska K. The impact of auxins used in assisted phytoextraction of metals from the contaminated environment on the alterations caused by lead (II) ions in the organization of model lipid membranes. Colloids Surfaces B. 2016;143:124-30.

38. Burdach Z, Kurtyka R, Siemieniuk A, Karcz W. Role of chloride ions in the promotion of auxin-induced growth of maize coleoptile segments. Ann Bot. 2014;114:1023-34.

39. Coyaud L, Kurkdjian A, Kado R, Hedrich R. Ion channels and ATP-driven pumps involved in ion transport across the tonoplast of sugarbeet vacuoles. Biochim Biophys Acta. 1987;902:263-8.

40. Trela Z, Burdach Z, Siemieniuk A, Przestalski S, Karcz W. Effect of Trimethyltin chloride on slow vacuolar (SV) channels in vacuoles from red beet (Beta vulgaris L.) taproots. PLoS One. 2015;10:e0136346.

41. Bertl A, Blumwald E, Coronado R, Eisenberg R, Findlay G, Gradmann D, et al. Electrical measurements on endomembranes. Science. 1992;258:873-4.

42. Molleman A. Patch clamping: an introductory guide to patch clamp electrophysiology. Chichester: Wiley; 2003.

\section{Ready to submit your research? Choose BMC and benefit from:}

- fast, convenient online submission

- thorough peer review by experienced researchers in your field

- rapid publication on acceptance

- support for research data, including large and complex data types

- gold Open Access which fosters wider collaboration and increased citations

- maximum visibility for your research: over $100 \mathrm{M}$ website views per year

At BMC, research is always in progress.

Learn more biomedcentral.com/submissions 